\title{
PROGRAM KEMITRAAN MASYARAKAT (PKM) KEWIRAUSAHAAN MAHASISWA FIS UNIMA PEMBUATAN DAN PEMASARAN MIE SAYUR TANPA PENGAWET
}

\author{
Sam Julius Richard Saroinsong \\ Fakultas Ilmu Sosial \\ Email: samsaroinsong@yahoo.com
}

\begin{abstract}
ABSTRAK
Lulusan perguruan tinggi memiliki potensi yang besar untuk dipersiapkan menjadi wirausahawan yang unggul, yang tidak hanya akan memandirikan dirinya secara ekonomi kelak, tetapi juga akan turut mengembangkan potensi ekonomi daerah yang pada gilirannya akan berdampak positif bagi perekonomian negara. Untuk mampu membentuk lulusan perguruan tinggi yang memiliki jiwa dan keterampikan kewirausahaan. Tujuan dari Program Kemitraan Mayarakat ini adalah untuk menghasilkan mahasiswa yang berwirausaha di bidang kuliner sehat yaitu dengan membuat dan memasarkan mie sayurtanpa pengawet. Metode yang digunakan dalam Program ini adalah Pelatihan, Coaching, dan Memasarkan langsung hasil yang dibuat.
\end{abstract}

Kata Kunci : Kewirausahaan, Mie sayur, Pemasaran

\section{PENDAHULUAN} ANALISIS SITUASI

Lulusan Perguruan Tinggi memiliki potensi yang besar untuk dipersiapkan menjadi wirausahawan yang unggul, yang tidak hanya akan memandirikan dirinya secara ekonomi kelak, tetapi juga akan turut mengembangkan potensi ekonomi daerah yang pada gilirannya akan berdampak positif bagi perekonomian negara.

Pendidikan kewirausahaan semakin digalakkan di perguruan tinggi agar mampu menyiapkan mahasiswa untuk berani mandiri, tidak lagi terfokus menjadi pencari kerja tetapi mampu menciptakan lapangan kerja bagi diri sendiri dan banyak orang.

Upaya perlu dilakukan untuk mengatasi pengangguran terdidik yang terus meningkat dengan menyiapkan lulusan perguruan tinggi yang tidak hanya berorientasi sebagai pencari kerja, tetapi juga sebagai pencipta lapangan kerja.Pendidikan kewirausahaan mesti berjalan secara berkesinambungan dan menjadi bagian yang tidak terpisahkan dari seluruh proses pendidikan di perguruan tinggi.

Tingginya angka pengangguran yang ditamatkan pendidikan tinggi di Indonesia mengalihkan perhatian kita untuk memburu model pendidikan macam apa yang cocok saat ini diterapkan di perguruan tinggi. Untuk menjawab persoalan tersebut di setiap perguruan tinggi saat ini sudah mulai mirintis program pendidikan kewirausahan termasuk di Universitas Negeri Manado (Unima). 
Sejak tahun 2012 Unima telah melakukan kerja sama dengan Humber Institute of Technology and Advanced Learning Canada dalam Sulawesi Economic Development Strategy (SEDS) Project yang mengimplemetasikan program kewirausahaan terapan (appliedentrepreneurship) dalam proses pembelajaran dan telah melaksanakan workshop yang sampai dengan tahun 2016 ada 6 workshop kewirausahaan terapan (durasi sekitar 360 jam kerja) untuk 18 dosen kewirausahaan serta serta melalui proyek ini telah didirikan pusat bisnis dengan nama Unima Humber Entrepreneurship Centre (UHEC). Gedung ini diresmikan oleh Duta besar Canada untuk Indonesia dan Rektor Unima pada tanggal 1 Februari 2016. Memiliki 2 ruang administrasi, 1 ruang meeting berkapasitas 20 orang, 5 ruang inkubator bisnis, 1 ruang pelatihan dan pameran berkapasitas 200 orang yang juga dapat dimanfaatkan sebagai ruang inkubator bisnis, 1 unit store untuk display produk dan penjualan, 1 gudang serta toilet.

Pusat Kewirausahaan UHEC ini dilengkapi dengan furniture standar kantor, fasilitas internet yang bisa diakses dari seluruh ruangan, sedang dikembangkan website yang mempromosikan Kewirausahaan Unima sekaligus penjualan produk kewirausahaan secara on-line (ecommerce) yang sementara ini dapat diakses di link 202.162.210.160/uhec. Setelah mendapatkan workshop dan menyusun modul, di tahun 2016 ini sedang dalam tahap pilot project pemberian mata kuliah Kewirausahaan Terapan 1 dan 2 (dalam 2 semester berturut) oleh 18 dosen yang sudah dilatih tersebut pada 4 Fakultas (di 13 Jurusan/Program Studi) di lingkungan Unima termasuk di Fakultas Ilmu Sosial (FIS).

Salah satu tujuan penyelenggaraan pendidikan di FIS Unima adalah Menghasilkan sarjana dan tenaga terdidik yang ahli, terampil, cerdas, mandiri, bermartabat serta profesional di bidang Sosial baik dalam kompetensi kependidikan dan non kependidikan dengan orientasi bahwa lulusan FIS Unima dapat bekerja sebagai PNS baik guru maupun non guru serta sebagai karyawan swasta untuk berbagai perusahaan. Pada kenyataan daya serap lulusan untuk suatu pekerjaan sangatlah minim sehingga mahasiswa perlu dibekali dengan pengetahuan kewirausahaan agar pada saat lulus mereka tidak lagi menunggu pekerjaan tetapi dapat menciptakan lapangan kerja menjadi pengusaha. Untuk itulah sejak tahun 2016 pendidikan kewirausahaan terapan 1 dan 2 telah di masukkan dalam kurikulum .

Iklim kondusif yang dicanangkan Ristek dan Dikti dalam membangun kewirausahaan mahasiswa melalui program PKMK dan PMW telah disambut dengan antusias oleh mahasiswa. Untuk FIS Unima Jumlah mahasiswa yang memenangkan Program kewirausahaan dari tahun ke tahun semakin meningkat mahasiswa yang masuk dalam program PMW. Adapun Jenis produk/ komoditas usaha yang sudah dihasilkan atau dijual oleh mahasiswa wirausaha (tenant) adalah: (1) layanan penjualan/penyewaan, pengetikan dan service komputer,(2) penjualan berbagai produk kuliner seperti makanan dan kue-kue, (3) penjualan pulsa dan layanan service HP, (4) produksi paket pebelajaran multi media (5) penjualan produksi hand made. (6) Bisnis OL.

Salah satu peluang usaha yang patut dilirik oleh mahasiswa adalah bidang kuliner seperti mie karena banyak orang yang gemar makan mie sehingga peluang ini dapat diambil menjadi peluang usaha bagi mahasiswa.

Produk usaha ini sangat potensial secara ekonomis untuk memenuhi kebutuhan segmen pasar baik di dalam kampus maupun di luar kampus. Namun keberlanjutan dan penanganan secara profesional usaha bisnis yang dikelola mahasiswa ini sering mencapai kegagalan atau tidak berkelanjutan, sehingga perlu proses yang mapan dalam membangun kapasitas entrepreneurshipmahasiswa secara sistemik melalui program PKM di Fakultas Ilmu sosial Alam Universitas Negeri Manado.

\section{PERMASALAHAN MITRA}

Permasalahan yang di hadapi mitra dalam hal ini mahasiswa Fakultas Ilmu Sosial Universitas Negeri Manado yaitu : 
- Ketergantungan biaya kuliah mahasiswa pada orang tua

- Keterlambatan membayar SPP karena belum menerima kiriman uang dari orang tua

- Kurangnya keinginan mahasiswa untuk berwirausaha

- Kurangnya pengetahuan mahasiswa tentang kewirausahaan

- Belum mampu melihat peluang bisnis yang ada di kampus dan daerah sekitar kampus

- Kebanyakan mahasiswa Belum memiliki usaha sendiri

- Banyaknya pengangguran terdidik (sarjana)

- Banyaknya keinginan mahasiswa melakukan bisnis kuliner yang sehat tetapi belum terlaksana

Peluang yang belum diambil yaitu Banyaknya keinginan civitas kampus untuk mengkonsumsi kuliner sehat seperti mie yang terbuat dari sayuran tanpa pengawet

\section{SOLUSI DAN TARGET LUARAN SOLUSI}

Dalam upaya mempersiapkan calon lulusan perguruan tinggi yang juga siap berwirausaha, maka harus membekali mahasiswa akan keterampilan kewirausahaan. Untuk dapat mewujudkan hal tersebut universitas harus memiliki kesiapan dalam arti memahami konsep dan wawasan kewirausahaan, memiliki bahan ajar serta metode pembelajaran yang tepat. Oleh karena itu perlu dilakukan kegiatan pengabdian pada masyarakat Program Kemitraan Masyarakat yang berjudul Kewirausahaan Mahasiswa akultas Ilmu Sosial Unima Pembuatan dan Pemasaran Mie Sayur tanpa Pengawet, dalam hal ini mahasiswa perlu diberikan pemahaman akan konsep kewirausahaan melalui pelatihan dan coaching serta membuat tempat agar mereka dapat memasarkan hasil produk yang telah mereka buat.

\section{a. METODE PELAKSANAAN POLA REKRUITMEN}

\section{Pola Rekruitmen kegiatan PKM FIS}

Unima melalui tahapan seleksi sebagai berikut :

5. Mensosialisasikan rekrutmen mahasiswa wirausaha

6. Membuka pendaftaran peserta di awal semester genap berjalan melalui pengisian Formolir yang telah disiapkan

7. Menseleksi calon peserta melalui formolir pendaftaran dan wawancara

8. Mengumumkan peserta yang layak mengikuti kegiatan PKM sebayak 20 mahasiswa

\section{b. METODE PENDEKATAN \\ POLA PELATIHAN}

Pola pelatihan mengikuti tahapan sebagai berikut :

Persiapan

6. Mempersiapkan pemateri baik dari dosen mata kuliah kewirausahaan maupun dari praktisi/ pengusaha terkait usaha.

7. Mempersiapkan pemateri dari lingkungan internal universitas yang memiliki kompetensi kewirausahaan dosen mata kuliah kewirausahaan atau pemateri dari lembaga yang terkait dengan pelaksanaan PKM yaitu Lembaga Pengabdian kepada Masyarakat.

3. Mempersiapkan jadwal pelatihan

4. Mempersiapkan materi pelatihan dan modul.

c. Kegiatan awal pelatihan adalah Penguatan sosialisasi pada tahap sebelumnya yaitu Penanaman mindset serta attitude kewirausahaan akan dilaksanakan selama 2 (dua) hari dengan berbagai kegiatan metode yang sudah dijalankan oleh pengelola dalam kegiatan kewirausahaan selama ini. Kegiatan ini juga menghadirkan mentor pengusaha muda, utamanya para alumni UNIMA juga pembicara dari tim UHEC.

Pelaksanaan

5. Pelatihan kewirausahaan internal akan di laksanakan di FIS minimal 3 jam per pertemuan selama 3 bulan dengan volume 2 kali setiap bulan.

6. Pelatihan dengan instruktur eksternal akan dirancang melalui forum pertemuan di pertengahan pelatihan. 
7. Pelatihan oleh instruktur eksternal menekankan pada aspek motivasi berwirausaha melalui sharing pengalaman serta belajar dari permasalahan kasus (case based learning) serta pelatihan untuk memperoleh keahlian yang sesuai.

8. Metode pelatihan yang digunakan adalah pelatihan partisipatif yang berorientasi pada keaktifan peserta pelatihan (mahasiswa) diantaranya metode diskusi, brain stroming, dan berbagai meode lainnya yang lebih variati. Pelatihan ini juga akan mengambil suatu tema khusus yang menyesuaikan dengan setiap jenis usaha tenant.

Evaluasi

Evaluasi pelaksanaan kegiatan ini untuk mengukur apakah kegiatan pelatihan ini sudah sesuai dengan kebutuhan tenant atau belum serta mengukur keberhasilan pelaksanaan kegiatan apakah seswuai dengan yang sudah direncanakan dalam mencapai tujuan.

\section{COACHING}

Persiapan

5. Mempersiapkan materi pendampingan yang terdiri dari data-data awal peserta, apabila yang sudah memiliki usaha data tersebut antara lain laporan keuangan dan laporan perkembangan usaha.

6. Mempersiapkan dosen pendamping yang akan melakukan coaching bisnis.

Pelaksanaan

6. Metode coaching terhadap bisnis adalah suatu program pembimbingan usaha tenant dimana tenant sebagai coacheeseolah-olah sedang magang di bisnisnya sendiri dan secara bertahap belajar menerapkan langkah-langkah bisnis di bawah bimbingan coach (pelatih)

7. Keluaran dari proses pendampingan adalah penetapan visi, misi dan budaya bisnis yang menjadi dasar pengelolaan bisnis, kemudian menentukan dan mengevaluasi strategi marketing, pengendalian keuangan, menentukan serta mengevaluasi sistem apa yang diperlukan dalam bisnis baik itu metode rekruitmen tenaga kerja, key performace indicator, ataupun analisa produktivitas.

8. Pada setiap akhir sesi coaching, tenant akan diberikan sejenis tugas yang diberi nama Home Fun. Home Fun berisi tugas terkait dengan materi pembahasan coaching di hari tersebut, sehingga pada pertemuan berikutnya dapat dibahas kemajuan usaha terkait materi yang dibahas.

9. Pertemuan dirancang dalam setiap tatap muka adalah selama minimal 3 (tiga) jam, setiap minggu

10. Dalam program ini coachingakan dilaksanakan selama 8 (delapan) bulan efektif baik untuk tenant yang baru merintis usaha atau bagi yang sudah mengimplementasikan bisnisnya secara nyata.

\section{Evaluasi}

Pada setiap akhir sesi coaching, tenant akan diberikan lembar evaluasi yang akan mengevaluasi kualitas coaching pada hari tersebut serta saran dan rekomendasi materi yang diinginkan.

\section{PEMBUATAN TEMPAT USAHA / PEMASARAN HASIL \\ Persiapan \\ Mempersiapkan lahan \\ Mempersiapkan peralatan \\ Pelaksanaan}

Membuat tempat usaha di lahan yang teladisediakan

Memasarkan hasi di tempat usaha yang telah dibuat

\section{Evaluasi}

Mengevaluasi keberadaan Usaha yang tlah dibuat

\section{HASILKEGIATAN \\ REKRUTMEN}


Rekruitmen kegiatan PKM FIS Unima melalui tahapan seleksi sebagai berikut :

1. Terjaringnya mahasiswa wirausaha di Fakultas Ilmu sosial.

2. Mahasiswa Mengikuti kegiatan pelatihan pembuatan mie tanpa pengawet dan pemasaran sebayak 25 mahasiswa.

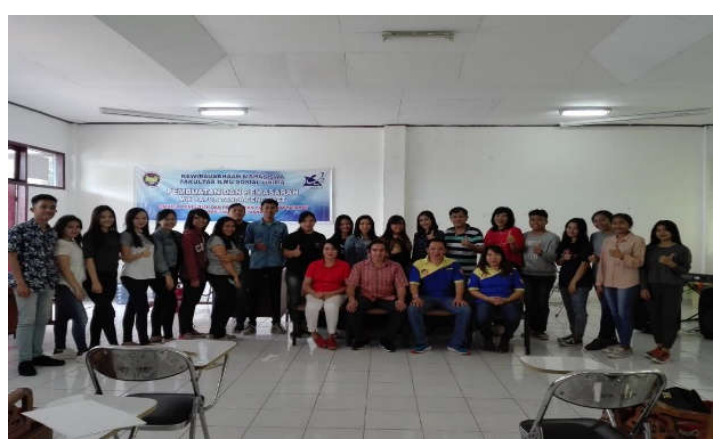

Gambar 1. Mahasiswa yang terjaring dalam program Kewirausahaan

\section{PELATIHAN}

Pola pelatihan mengikuti tahapan sebagai berikut :

\section{Persiapan}

1. Pemberian bahan materi baik dari dosen mata kuliah kewirausahaan maupun dari praktisi/ pengusaha terkait usaha.

2. Pemberian Materibahan dari lingkungan internal universitas yang memiliki kompetensi kewirausahaan dosen mata kuliah kewirausahaan atau pemateri dari lembaga yang terkait dengan pelaksanaan PKM yaitu Lembaga Pengabdian kepada Masyarakat.

3. Jadwal pelatihan

4. Materi pelatihan dan modul.

5. Kegiatan awal pelatihan adalah Penguatan sosialisasi pada tahap sebelumnya yaitu Penanaman mindset serta attitude kewirausahaan akan dilaksanakan selama 2 (dua) hari dengan berbagai kegiatan metode yang sudah dijalankan oleh pengelola dalam kegiatan kewirausahaan selama ini. Kegiatan ini juga menghadirkan mentor pengusaha muda, utamanya para alumni UNIMA juga pembicara dari tim UHEC.
1. Pelatihan kewirausahaan internal di laksanakan di FIS minimal 3 jam per pertemuan selama 3 bulan dengan volume 2 kali setiap bulan.

2. Pelatihan dengan instruktur eksternal yang diberikan melalui forum pertemuan.

3. Pelatihan oleh instruktur eksternal menekankan pada aspek motivasi berwirausaha melalui sharing pengalaman serta belajar dari permasalahan kasus (case based learning) untuk memperoleh keahlian dalam hal ini pembuatan mie sayur tanpa pengawet dengan instruktur pengusaha mie Steven.

4. Metode pelatihan yang digunakan adalah pelatihan partisipatif yang berorientasi pada keaktifan peserta pelatihan (mahasiswa) diantaranya metode diskusi, brain stroming, dan berbagai meode lainnya yang lebih variati. Pelatihan ini juga akan mengambil suatu tema khusus yang menyesuaikan dengan setiap jenis usaha tenant.

\section{Evaluasi}

Evaluasi pelaksanaan kegiatan ini untuk mengukur apakah kegiatan pelatihan ini sudah sesuai dengan kebutuhan tenant atau belum serta mengukur keberhasilan pelaksanaan kegiatan apakah seswuai dengan yang sudah direncanakan dalam mencapai tujuan.

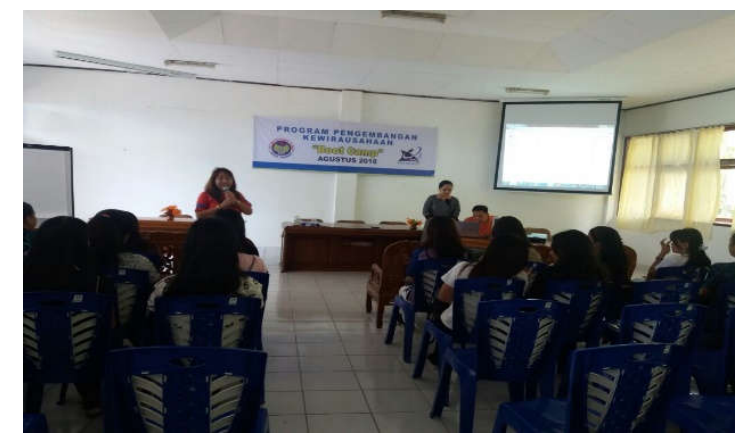

Gambar 2. Pelatihan dengan Instruktur dari UHEC

\section{Pelaksanaan}




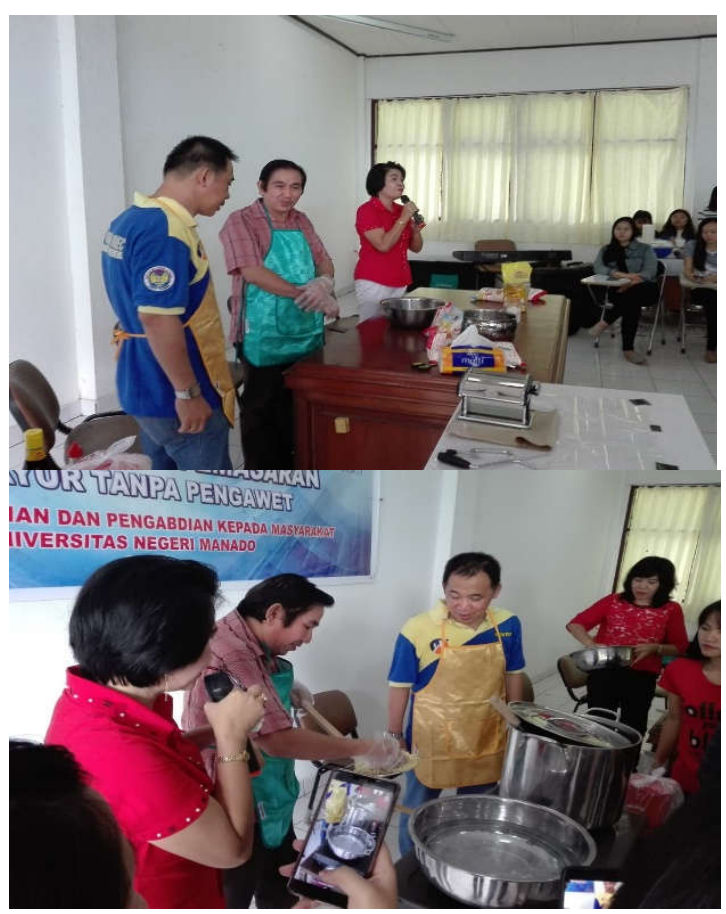

Gambar 3. Pelatihan Pembuatan mie sayur dengan instruktur eksternal

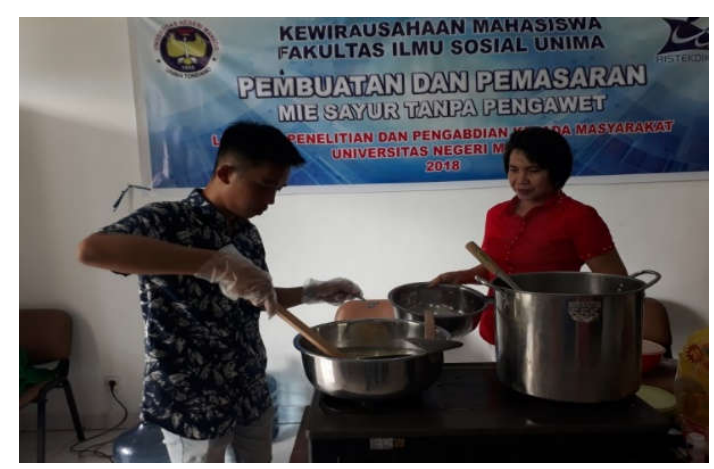

Gambar 4. Mahasiswa melakukan uji coba 


\section{PEMASARAN HASIL}

Persiapan

Mempersiapkan lahan

Mempersiapkan peralatan

Pelaksanaan

Membuat tempat usaha di lahan yang telah disediakan

Memasarkan hasil di tempat usaha yang telah dibuat

\section{Evaluasi}

Mengevaluasi keberadaan Usaha yang telah dibuat

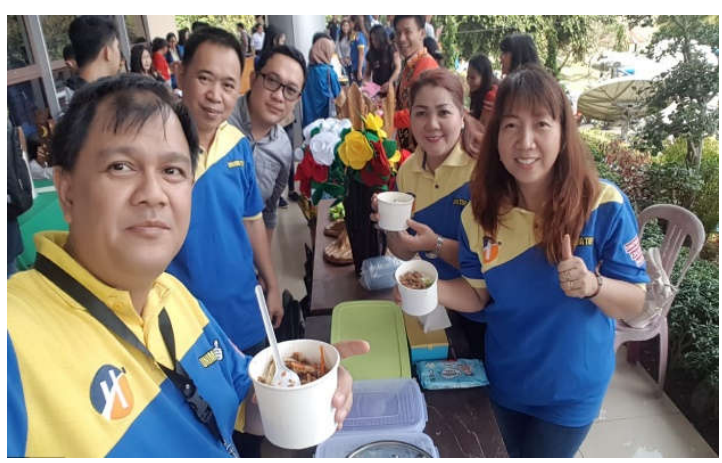

Gambar 5. Pemasaran Mie Sayur

\section{PENUTUP \\ KESIMPULAN}

Kegiatan kewirausahaan yang telah diadakan di Fakultas Ilmu Sosial telah terlaksana dengan baik yaitu melalui kegiatan Rekrutmen, Pelatihan, Memasarkan hasil

\section{SARAN}

Kegiatan

Kewirausahaan memerlukan dukungan dari berbagai pihak baik dalam ruang lingkup pimpinan universitas,Fakultas dan Jurusan/Prodi

\section{REFERENSI}

Hisrich, R. D. \& Peters, M. P. 1995. Entrepreneurship. Starting. Developing. and Managing A New Entreprise. New York:

Management, Millenium Edition. Tenth Edition. Prentice-Hall.

Susanto, A. B. 2007.Corporate Social Responsibility. Jakarta: The Jakarta Consulting Group. ..

World Intellectual Property Organisation (WIPO). 2008. Membuat Sebuah Merek, Pengantar Merek Untuk Usaha Kecil dan Menengah. Terjemahan KADIN Indonesia.

Zimmerer, W. T. \& Scarborough, N. M. 1996. Entrepreneurship and The New Venture Formation. New Jersey: Prentice Hall Inc. 